\title{
A practical Recuperated Split Cycle engine for low emissions and high efficiency
}

\author{
Author, co-author (Do NOT enter this information. It will be pulled from participant tab in \\ MyTechZone) \\ Affiliation (Do NOT enter this information. It will be pulled from participant tab in MyTechZone)
}

\begin{abstract}
The Recuperated Split Cycle Engine is a new type of ICE, offering a step change in efficiency and tailpipe emissions. It targets the heavy duty, long-haul sector (trucks, off-highway, rail, shipping), where electrification is most challenging, and distributed generation, where capacity is required to support rising electrification. The engine separates cold (induction, compression) and hot (combustion, expansion) parts of the cycle; waste exhaust heat is recovered between them via a recuperator, as in a recuperated gas turbine. Recent research presented at this conference [1] shows that the sonic airflows seen in the induction event give rise to extraordinary fuel mixing and clean, cool combustion, with potential for after-treated emission levels between SULEV and zero-impact (either unmeasurable or below ambient). Recuperation and thermal insulation of the hot cylinder (both feasible within the capability of common materials) also enable high thermal efficiency, with a flatter efficiency map than a conventional ICE. Combining the two attributes, and introducing sustainable fuels, places this readily manufactured, affordable technology on a par with battery-electric and fuel cell propulsion. Results from simulation to optimise the concept are described. A Ricardo WAVE model was built, with validation of key inputs such as valve breathing, heat transfer and burn-rates from relevant experimental research data. The model was used to develop the cycle around three concepts - a basic layout, "ThermoPower", was shown to be capable of over $10 \%$ fuel saving; "Wet ThermoPower" uses water injection as a compression coolant for greater efficiency, while the ultimate "CryoPower" injects Liquid Nitrogen for quasi-isothermal compression and charge dilution. The optimisation process and practical details are described, especially the development of the critical recuperator, which is subjected to high pressure and temperature; management of its thermal expansion and manufacturing process have been optimised to minimise add-cost over a current ICE bill of materials.
\end{abstract}

\section{Introduction}

Electrification is becoming the accepted solution to environmental challenges in the light duty sector [2,3]. Developments in battery, motor and charging technology provide a solution that increasingly meets the user's needs in terms of range and utility, while adding the bonus of quiet, effortless traction. While capital costs remain high today, some projections indicate a point of cross-over with a comparable ICE vehicle within the next ten years. Emissions from the powertrain are zero at point of use, and de-carbonisation of energy supply, both for manufacture and re-charging, can be aligned to sustainable energy policies. However, this strategy does not

Page 1 of 12 translate so readily to heavy duty, long-haul sectors which currently employ the ICE, usually in the form of a turbocharged Diesel engine. These sectors include Medium and Heavy duty trucks; Construction, industrial and agricultural vehicles; Rail vehicles; Marine propulsion; and Distributed power generation sets.

Unlike the passenger car, these sectors are often characterised by very high levels of utilisation (12-24 hours per day) and load factor (often sustained peak torque or rated power), which puts a premium on range (or energy density of the "fuel" / energy carrier) and refuelling / charging time [4].

Table 1: - Energy density \& fuel payload comparison for a 40-tonne GTW, 500-mile semi-trailer truck.

\begin{tabular}{|c|c|c|c|c|}
\hline & $\begin{array}{l}\text { Li-Ion } \\
\text { Battery }\end{array}$ & $\begin{array}{l}\text { Li-Ion + } \\
\text { Catenary }\end{array}$ & Hydrogen & Diesel \\
\hline $\begin{array}{l}\text { Energy } \\
\text { Converter } \\
\text { (Powertrain) }\end{array}$ & \multicolumn{2}{|c|}{ Inverter + E-Motor } & $\begin{array}{l}\text { PEM Fuel } \\
\text { Cell }\end{array}$ & $\begin{array}{l}\text { 4-stroke } \\
\text { ICE }\end{array}$ \\
\hline $\begin{array}{l}\text { Stored energy } \\
\text { density } \mathrm{Wh} / \mathrm{kg} \\
\text { inc Tank }\end{array}$ & \multicolumn{2}{|c|}{$\begin{array}{l}200 \text { (of which } 85 \% \\
\text { usable) }\end{array}$} & 2,700 & 10,000 \\
\hline $\begin{array}{l}\text { Powertrain } \\
\text { efficiency } \\
\% \text { Tank to } \\
\text { Wheel }\end{array}$ & \multicolumn{2}{|l|}{$85 \%$} & $42.5 \%$ & $36.5 \%$ \\
\hline $\begin{array}{l}\text { Usable Energy } \\
\text { Density } \\
\text { (Stored x Effy } \\
\text { x DoD) Wh/kg }\end{array}$ & \multicolumn{2}{|c|}{$\begin{array}{l}123 @ 85 \% \text { Depth } \\
\text { of Discharge }\end{array}$} & 1170 & 3700 \\
\hline $\begin{array}{l}\text { Fuel+Tank } \\
\text { Mass, } 500 \mathrm{mi} \\
(800 \mathrm{~km}) \\
\text { range, } \quad \mathrm{Kg}\end{array}$ & $\begin{array}{l}8,570 \\
(500 \mathrm{mi})\end{array}$ & $\begin{array}{l}1,714 \\
(100 \mathrm{mi})\end{array}$ & 1000 & 260 \\
\hline $\begin{array}{l}\text { Point-of-use } \\
\text { emissions }\end{array}$ & Zero & & $\begin{array}{l}\text { Mostly } \\
\text { water }\end{array}$ & EuVI/US10 \\
\hline
\end{tabular}

Table 1 compares expected energy densities and fuel tank / energy carrier masses for four competing options for a long-haul truck of the early-mid 2020s. Batteries for full-range functionality adversely impact payload, meaning more trucks for the same task. Their energy density may improve, but light duty technologies may not meet the more aggressive requirements of heavy duty. In these large sizes, the voltage and current required for fast charging (up to $2 \mathrm{MW}$ ) are a challenge that will not diminish with time. Use of hydrogen and a fuel cell, or a catenary system with a smaller battery for the first / last 
100 miles, reduces these challenges, but both require unprecedented infrastructure investment to be useable.

This situation poses a simple question: What if the ICE could perform well enough to compete with these zero-emission alternatives, both for local air quality and efficient use of sustainable energy? In practical terms, this necessitates very low engine-out emissions, so that an after-treated system can approach the point of zero impact; and high thermal efficiency, so that carbon emissions can be reduced and future, more costly sustainable fuels can be used sparingly. This paper, together with that of Morgan et al [1], presents the development of recuperated split-cycle engines that meet those needs.

\section{The Recuperated Split Cycle Engine}

\section{Split Cycle Engines}

The split cycle separates induction/compression and combustion/expansion phases of the four-stroke cycle into a pair of two-stroke cylinders, allowing each to be optimised for its purpose. The principle is by no means new. The Backus Water Motor Company produced engines with separated compression and expansion from 1891 [5], while a form of split-cycle was embodied in Ricardo's Dolphin engine in 1905 [6], renowned at the time for clean and efficient operation. More recently the principle has been explored by Scuderi [7,8], Caterpillar [9], Coney [10] and others [11], although most have not included recuperation in their cycles, to the detriment of efficiency potential.

\section{Recuperation}

\section{Recuperator}

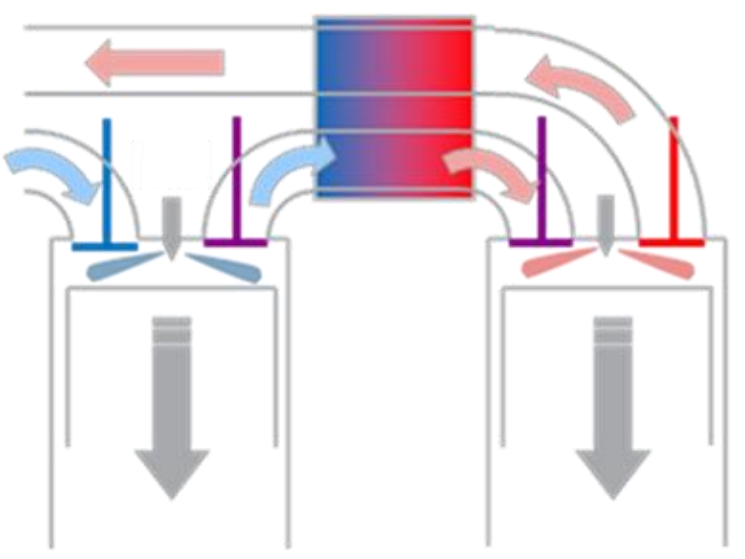

\section{Induction \& Compression (Cold)}

\section{Combustion \& Expansion (Hot)}

Figure 1: Recuperated Split Cycle

Figure 1 shows the basic principles of the recuperated split cycle. A "cold" compressor cylinder inducts air (from a conventional aftercooled turbocharging system), then compresses it in much the same manner as a 4-stroke cycle, but at TDC the air is discharged - the compression cycle is very similar to an industrial compressor, except that a higher pressure ratio, circa 20:1, is required. The discharged air is passed through a recuperator, where hot exhaust gases add heat. Again, this principle is well known in the recuperated gas turbine.

The air is now a hot, supercritical fluid - up to 70 bar and $700^{\circ} \mathrm{C}$. It is "injected" into the expander cylinder at around TDC, where it meets injected fuel, giving rise to a very energetic mixing event. It is this mixing, plus the controllability of intake conditions at the point of ignition, which are believed to be responsible for a cool, homogeneous combustion phenomenon (similar to HCCI, but much more controllable and stable), and very low levels of engine-out soot and NOx $[1,12,13]$. Research has already demonstrated that SULEV NOx levels are possible; with development, tailpipe NOx can be reduced below observed city ambient levels.

\section{Efficiency improving features}

Two measures extract maximum efficiency from the expansion event. First, the expander cylinder can be of different size to the compressor, enabling a Miller-cycle principle to be employed. Past research has shown that a displacement of up to three times that of the compressor can be beneficial $[8,10]$. Second, the expander can be insulated. Thermal insulation was extensively researched on 4-stroke diesel engines in the 1980s, with limited success [14]. The issue was that benefits to the combustion and expansion processes were negated both by a lack of added expansion capacity, and by a detrimental impact of hot walls on the colder intake and compression events. With an enlarged, dedicated hot cylinder, these issues do not apply; insulation is able to convert combustion heat into either useful work, or hot exhaust whose enthalpy is recycled via the recuperator.

\section{Isothermal and cooled compression}

The first recuperated split-cycle piston engine of recent times was the Isoengine proposed by Coney [10], with two levels of prototype eventually being built and tested $[15,16]$. This engine added a final factor to the thermodynamic cycle, that of quasi-isothermal compression. If the compression cylinder is kept cool during the compression process, a lower level of compressor work is required (similar to the effect of multiple stages of intercooling), while the recuperator provides sufficient heat to return the compressed gas to the desired hot state for combustion. The Isoengine employed nonevaporating water as a compression coolant, achieving compressor discharge temperatures of below $90^{\circ} \mathrm{C}$, compared to an adiabatic discharge of over $260^{\circ} \mathrm{C}$ [16]. This equated to a $17 \%$ reduction in compressor work, and as this will be around $30 \%$ of gross expander output, an overall increase in thermal efficiency of more than 5\% results from this effect alone. The authors reported potential for fuelto-electricity efficiency of $57 \%$ to $60 \%$ for a $3 \mathrm{MW}$ unit, although this was not fully demonstrated in hardware.

Non-Evaporating water is a convenient, non-toxic cooling fluid with good specific heat capacity. However, the quantity required is relatively large, as sensible heating provides just $125 \mathrm{~kJ} / \mathrm{kg}$ of cooling [17]. In addition, the post-compression separator and water cooling system are relatively large for transport use; the practicalities of ejecting liquid-phase water as a mixture with compressed gas through a discharge valve tend to limit this type of device to low operating speeds. A greater cooling effect can be obtained by using the latent heat of vapourisation of the water $(2257 \mathrm{~kJ} / \mathrm{kg})$, meaning lower quantities injected, a finer spray with better heat transfer, and no

Page 2 of 12

$10 / 19 / 2016$ 
liquid to eject at the top of compression. However, this approach is limited by the pressure and temperature conditions during compression, relative to how water's boiling point varies with pressure. Figure 2 shows the evolution of temperature in a typical polytropic compression of a split-cycle engine, compared to the boiling point of water at the same pressure. The ability to cool by vapourisation only arises after $60^{\circ} \mathrm{BTDC}$ ( $11.5 \mathrm{bar}$ pressure). In the Isoengine compressor test cited above, the discharge pressure was 13 bar; here, water boils at $190^{\circ} \mathrm{C}$, compared to an adiabatic discharge of $260^{\circ} \mathrm{C}$ and an observed convection-cooled temperature of below $90^{\circ} \mathrm{C}$ [16], so a vapourising-water approach would achieve less than half of the effect observed.

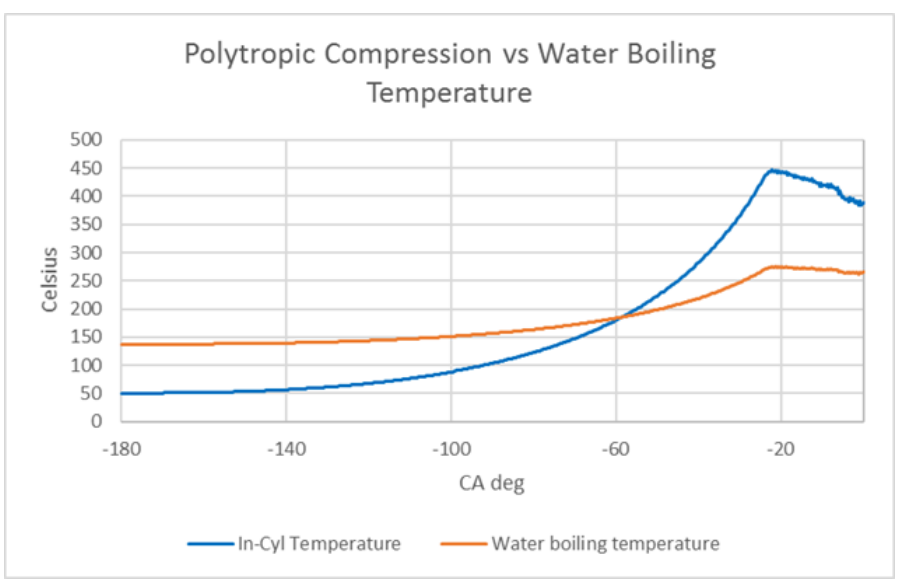

Figure 2: Polytropic compression and water boiling temperatures.

There is certainly great value to the vapourised-water approach, as it represents both a cost-effective half-way house to full quasiisothermal compression, and a potential means of managing excessive combustion temperatures in the expander. However, to obtain the most efficient, near-isothermal compression in a transport or mobile engine, a further approach is required. Liquid Nitrogen (LiN) offers a solution, being a readily available industrial fluid with a very low boiling point compared to compression conditions. $\mathrm{LiN}$ has a lower latent heat of vapourisation than water $(199 \mathrm{~kJ} / \mathrm{kg}$ vs $2257 \mathrm{~kJ} / \mathrm{kg}$ at standard conditions), but this value is substantially increased by sensible heat, to around $475 \mathrm{~kJ} / \mathrm{kg}$ [17].

This study has therefore looked at the efficiency potential of three variants of the recuperated split-cycle engine [18]: "Dry

ThermoPower" is a basic unit without any form of compression cooling apart from the intercooler after the turbo-compressor; "Wet ThermoPower" adds injection of water into the compressor, up to the limit of what will vapourise; and finally "CryoPower" uses $\mathrm{LiN}$ as a compression cooling medium.

\section{Concept Modelling Methodology}

\section{WAVE models}

A single cylinder research engine, representing the expander half of the cycle, has been used to demonstrate the potential of the technology for low emissions, especially NOx $[1,12,13]$. However, this approach is of limited use for optimising the wider system, as the compressor hardware is absent, and losses to friction and heat are not representative of a better integrated multi-cylinder unit. To optimise a concept for a first fully integrated multi-cylinder prototype, a model was built using Ricardo WAVE, a one-dimensional virtual-engine Page 3 of 12 tool that embraces models of gas dynamics, component maps, fuel injection, combustion and heat transfer [19]. Early studies [17] had indicated potential for an indicated thermal efficiency of at least $60 \%$ with effective recuperation and compression cooling, and $70 \%$ with insulation of the expansion process added. The challenge now was to develop a more detailed and realistic model, with validation of each design input against criteria suitable for building a real engine.

\begin{tabular}{|c|c|c|}
\hline \multicolumn{2}{|c|}{$\begin{array}{l}\text { Validation - Subsystem Level } \\
\text { Ports \& Valve Lifts; Recuperator \& Intercooler } \\
\text { Effectiveness; Turbocharger Efficiency } \\
\text { Burnrates and Heat Transfer; Friction }\end{array}$} & $\begin{array}{l}\text { Validation - System Level } \\
\text { Matching to Titan single } \\
\text { cylinder engine - Breathing, } \\
\text { combustion \& expansion }\end{array}$ \\
\hline & \multicolumn{2}{|c|}{ 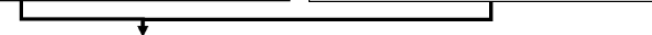 } \\
\hline $\begin{array}{c}\text { Initial WAVE } \\
\text { model [17] }\end{array}$ & $\begin{array}{c}\text { Cylinder Pair Model } \\
\text { Dry \& Wet ThermoPower } \\
\text { CryoPower }\end{array}$ & $\begin{array}{c}\text { Optimisation } \\
\text { Design of Experiments } \\
\text { Stochastic Process Model }\end{array}$ \\
\hline $\mathrm{A} 80 \bigcirc_{\mathrm{B} 100 \mathrm{C}}$ & & \multirow{3}{*}{$\begin{array}{c}\text { Common Geometry } \\
\text { Compress / Expand ratio } \\
\text { Valve Timings }\end{array}$} \\
\hline A30 & & \\
\hline Keypoints & & \\
\hline \multicolumn{2}{|c|}{$\begin{array}{l}\text { Validation - Real Parts } \\
\text { Recuperator, } \\
\text { Turbocharger } \\
\text { Insulation Strategy } \\
\text { Donor Engine }\end{array}$} & $\begin{array}{l}\text { Multi Cylinder Model } \\
\text { "Mule" prototype engine } \\
\text { Final optimisation }\end{array}$ \\
\hline
\end{tabular}

Figure 3: Concept Development and Modelling Methodology

Figure 3 shows the approach taken. Modelling has focused on three keypoints in the engine's speed-load map:

1. A30 (1100 rpm, 30\% load) represents highway cruise

2. A80 (1100 rpm, $80 \%$ load) is the "efficiency eye" of a typical 4-stroke engine, and represents uphill cruise

3. B100 (1600 rpm, 100\% load) is the engine's rated power.

To minimise model run-time, initial optimisation was performed using a cylinder pair, representing the power output of one-third of a typical 13 litre, $375 \mathrm{~kW}$ truck engine. In this approach, the sizes of compressor and expander cylinders are very different, which is inconvenient for conventional engine construction but permitted a pragmatic first step to a multi-cylinder model with unequal numbers of each cylinder type.
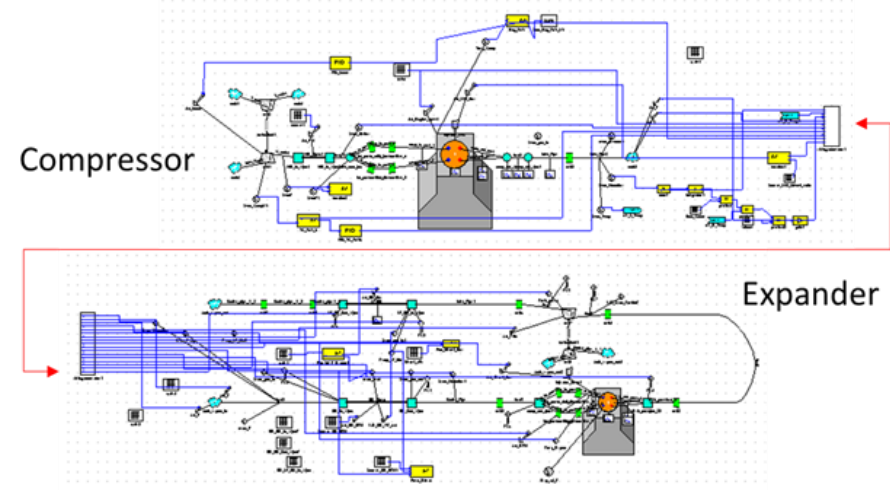

Figure 4: Illustrative split WAVE cylinder-pair model

The standard features of the WAVE code were used to build the recuperated split cycle. In most cases, these features (cylinders, ports, valves, heat exchangers, turbochargers) were performing their 
originally intended function. For the injection of the compressor cooling fluid (water or LiN), the fuel injection model was used, with appropriate fluid properties, and combustion disabled. However, the model requires both compressor and expander cylinders, and it was not possible to disable combustion in just some cylinders. Therefore, a "split" model (two joined models) was built, with one model for the compressor and one for the expander. Exchange of fluid properties and shaft torques happened via the interface normally used by WAVE to link dynamically to other codes. A single-piece model of the Dry ThermoPower engine (which has no compressor cooling fluid, so does not have this problem) was used to validate that this split model performed correctly. The full detail of the split cylinderpair model is illustrated in Figure 4. The validation philosophy for the cylinder-pair model was firstly to ensure that every significant component of the model was using values that did not exceed known state-of-the-art, and then to model the Titan single-cylinder expander at conditions used for emissions development $[1,12,13]$, and check the match.

\section{Key Engine Subsystems - Modelling Assumptions}

\section{Breathing, Ports and Valvetrain}

The recuperated split-cycle engine has four distinct valve types intake and discharge of the cold compressor cylinder, air injection and exhaust in the hot expander. The first and last - intake and exhaust - are similar to their 4-stroke equivalents, so standard bestin-class valve lift profiles and discharge coefficients were used. The exhaust valve's timing was controlled with a cam profile, but the intake was modelled as a low inertia self-acting device, as a simple means to establish the required timing. In a real engine, it would be cam-operated, to reduce drag losses.

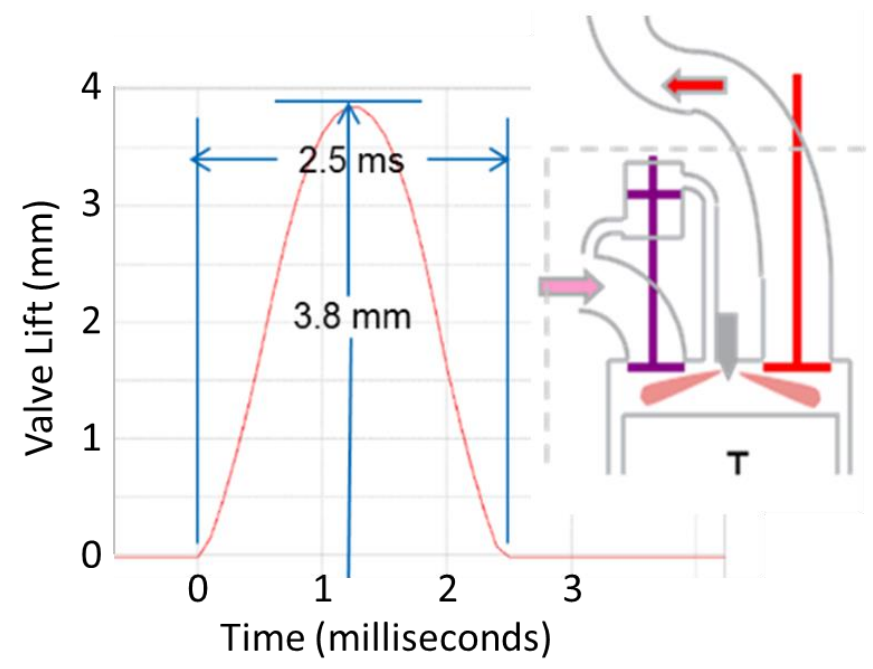

Figure 5: Expander intake (air injection) valve

Compressor discharge was modelled as another self-acting valve, and here this is likely to be adopted as a hardware solution. Industrial compressors use this principle, often with a simple disc valve; the earlier IsoEngine $[10,15,16]$ employed a reversed poppet valve that opened into the discharge port, which is likely to be more efficient, so was assumed as a basis for this study. There are limited data on the discharge coefficient of this type of valve, but standard heavy-duty port characteristics (derived for much lower pressures) were found to be adequate. Further rig tests are planned to study the intended discharge valve's flow characteristics in more detail.

Page 4 of 12
The air-injection valve in the expander is a critical part of the system, as its open period can be as little as 20 crank degrees. However, high air density means that a relatively low lift $(2-3 \mathrm{~mm})$ is required. The valves on the Titan single-cylinder engine were actuated with a fully variable, electro-hydraulic system $[1,12,13,17]$. This is not a production solution, so a cam-operated valve was designed using standard practices. Lifts of over $3 \mathrm{~mm}$ were found to be feasible in a medium duty engine; the solution uses a balance-piston to keep it closed against a port pressure (figure 5). This feature has been proven on the IsoEngine $[10,15,16]$, and more recently on the Dearman cryogas expander engine [20,21]. Again, standard low-pressure port breathing characteristics were taken as a starting point for modelling, and a rig study is underway to develop improved characterization at high pressures. A key issue here is that the flow through the valve can approach choked conditions $[1,12,13]$.

\section{Burnrates and Heat Transfer}

Initial research on the single-cylinder expander engine [1, 12,13,17] showed that lowest NOx emissions tended to be associated with a fast burn-rate, indicating a pre-mixed combustion regime. The WAVE model therefore used a fast burn profile derived directly from heat release data on the single-cylinder engine, with a 10-90\% burn angle of 6.5 crank degrees.

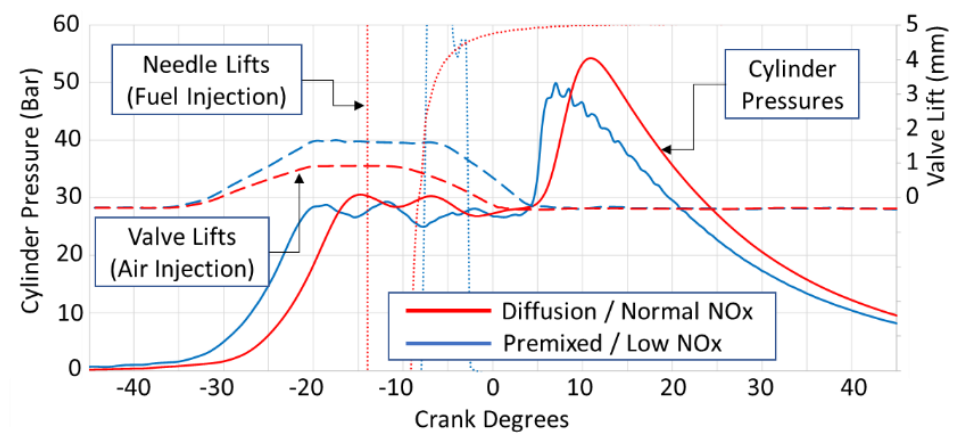

Figure 6: Measured pressure traces for Cool and Diffusional combustion

Figure 6 compares measured cylinder pressure traces for the two combustion modes as observed on the Titan engine. These data also show that the intake (air injection) event is effective, as the cylinder's dead volume reaches equilibrium pressure long before the valves close.

The recuperated split-cycle benefits from thermal insulation of its hot, expander cylinder. The so-called "adiabatic engine", with its combustion chamber insulated by a layer of low-conductivity ceramics, was the subject of much experimentation in the 1980s [14]. While some benefits were observed, there was a general tendency that gains in the hot part of the cycle (combustion and expansion) were offset by degraded volumetric efficiency and heating of the compression phase. The split cycle avoids these drawbacks, because its hot cylinder is always hot. It also avoids adverse effects on NOx, because as described above, elevated mean temperature facilitates lower peak temperature via pre-mixed combustion.

WAVE generates in-cylinder heat transfer coefficients using the Woschni model [22], which is based on the four-stroke cycle, and radiative heat transfer is treated implicitly within an essentially convective correlation. This is unlikely to represent a highlyinsulated, hot-only cylinder correctly, especially with respect to radiation where a hot surface will dramatically reduce the heat absorbed. A correction factor has been applied for initial modelling, 
based on one-dimensional heat transfer models, using results from an insulated four-stroke engine as a guide [14,23]. The expectation is that heat transfer levels can be halved compared to a non-insulated expander, and discussions with current suppliers of spray coatings (Partially Stabilised Zirconia - PSZ) have confirmed that the required level of insulation is possible. A prototype piston crown, which combines a thin PSZ later with elongated heat-paths in its metal substrate, is shown in Figure 7.

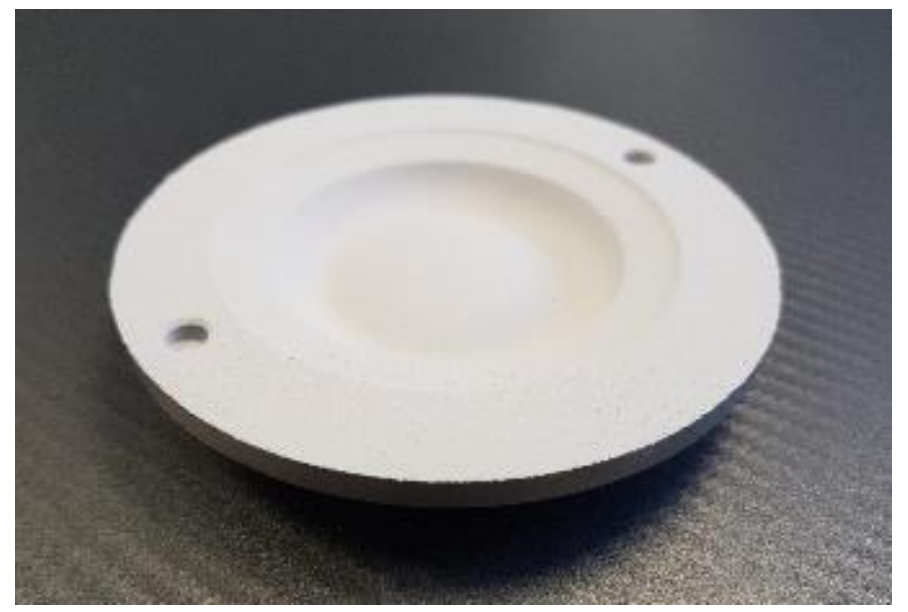

Figure 7: Spray-coated insulated piston crown.

\section{Thermofluid Components}

These consist of the turbocharger, intercooler and recuperator. The turbocharger (not shown in Figure 1) supplies boost air to the piston compressor as in a standard 4-stroke engine. For the cylinder-pair model, the turbo-compressor was modelled with fixed efficiency and intercooler outlet temperature. The turbine can be placed either upstream or downstream of the recuperator; whichever component is placed first receives the greatest exhaust enthalpy (and therefore potentially performs better) but must be able to resist the highest temperature. Again, a fixed efficiency was assumed for initial optimisation, but this was corrected according to location before or after the recuperator - in the downstream position, cooler exhaust gases give rise to a much lower level of radiative loss from the turbine housing.

Table 2: Assumed model values for thermo-fluid components

\begin{tabular}{|l|l|l|}
\hline Assumed Value & $\begin{array}{l}\text { Turbine Before } \\
\text { Recuperator }\end{array}$ & $\begin{array}{l}\text { Turbine After } \\
\text { Recuperator }\end{array}$ \\
\hline Turbo-compressor Efficiency & $79 \%$ & $79 \%$ \\
\hline $\begin{array}{l}\text { Intercooler Outlet } \\
\text { Temperature }\end{array}$ & $50^{\circ} \mathrm{C}$ & $50^{\circ} \mathrm{C}$ \\
\hline Turbine Efficiency & $70 \%$ & $74 \%$ \\
\hline $\begin{array}{l}\text { Turbine Inlet Temperature } \\
\text { Limit }\end{array}$ & $\begin{array}{l}900^{\circ} \mathrm{C} \text { steady, } 1000^{\circ} \mathrm{C} \\
\text { intermittent (based on NG truck) }\end{array}$ \\
\hline Recuperator Inlet Temp Limit & $750^{\circ} \mathrm{C} \mathrm{@} \mathrm{70} \mathrm{bar,} 800^{\circ} \mathrm{C} \mathrm{@} \mathrm{40} \mathrm{bar}$ \\
\hline $\begin{array}{l}\text { Recuperator HP Inlet Pressure } \\
\text { Limit }\end{array}$ & 70 bar abs & 70 bar abs \\
\hline
\end{tabular}

The recuperator is probably the most critical component of the entire concept, being subjected to high pressures and temperatures (up to 70 bar, and $800^{\circ} \mathrm{C}$ ) simultaneously. It is described in more detail in a subsequent section, and its effectiveness was adopted as an optimisation variable - while higher effectiveness is always more

Page 5 of 12 efficient in principle, a lower value can enable component temperature limits to be met in an otherwise efficient configuration of other variables.

Assumptions, shown in Table 2, were subsequently validated against vehicle data (intercooling), with a turbocharger supplier (efficiencies), and against recuperator design predictions.

\section{Friction}

Friction was treated as a post-process step, meaning that the WAVE model was used to predict and optimise indicated performance. It was assumed that friction would be similar to a state-of-the-art heavyduty engine, and benchmark data were used as a starting point. Modifications were then applied for three factors: Power density is reduced (because extra efficiency can only be gained by extra expansion), but peak cylinder pressure is also reduced (to below 140 bar, compared to 240), and finally ancillary drive power to both the fuel and coolant pumps is reduced, because the engine is more efficient and rejects less heat to coolant. Values used, expressed as a percentage of indicated power, are shown in Table 3 for three keypoints.

Table 3: Key-points and Friction assumptions

\begin{tabular}{|c|c|c|c|c|c|c|}
\hline 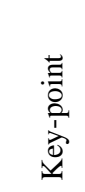 & 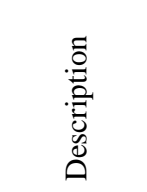 & 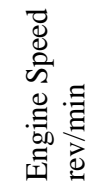 & 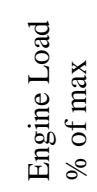 & 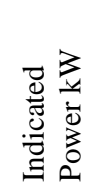 & 葋总 & 总 \\
\hline A 30 & $\begin{array}{l}\text { Highway } \\
\text { Cruise }\end{array}$ & 1100 & $30 \%$ & 35 & $8.5 \%$ & $7.0 \%$ \\
\hline A80 & $\begin{array}{l}\text { Efficiency } \\
\text { "eye" }\end{array}$ & 1100 & $80 \%$ & 85 & $5.2 \%$ & $4.3 \%$ \\
\hline B100 & $\begin{array}{l}\text { Rated } \\
\text { Power }\end{array}$ & 1600 & $100 \%$ & 130 & $6.6 \%$ & $5.5 \%$ \\
\hline
\end{tabular}

Finally, the split-cycle engine also has potential for lower cooling-fan power. This is not normally included in "brake" power, SFC or thermal efficiency measurements, but is a very relevant factor. Fan power can account for as much as $5 \%$ of brake power [24]; because of reduced heat rejection to coolant, this can be reduced by as much as half. To make a fair /comparison as seen by the user of a vehicle, the results for recuperated split-cycle variants are presented as a "corrected" Brake value taking the fan power reduction into account.

\section{Validation against single cylinder engine}

The WAVE model's output was cross-checked against data from the single-cylinder Titan engine [1,12,13,17], a 1.13 litre (105 x 130) research unit configured to represent the expander cylinder. The compressor part of the model was removed, and the expander model was adjusted to represent the Titan's geometry, measured timings of the Titan's electro-hydraulic valves, and its lack of thermal insulation. The primary focus of the validation was a stepwise matching of the pressure-crank angle curve, as illustrated in Figure 8. Good correlation was achieved at three different air injection pressures, both in terms of the cylinder filling process, and combustion / expansion, without adjustment to standard breathing or heat transfer parameters. Finally, the indicated thermal efficiency from the WAVE model was compared to measurements from the engine. Brake values and a friction estimate were used, as the 
engine's TDC location was not sufficiently accurate for a direct IMEP calculation. Over a load range of 30-60\%, WAVE predicts around 53\% ITE, the observed values were 50-54\%. These values are not meaningful in an absolute sense, as they lack both compressor drive power and insulation, but their alignment is another indication that WAVE can capture expander thermodynamics correctly.

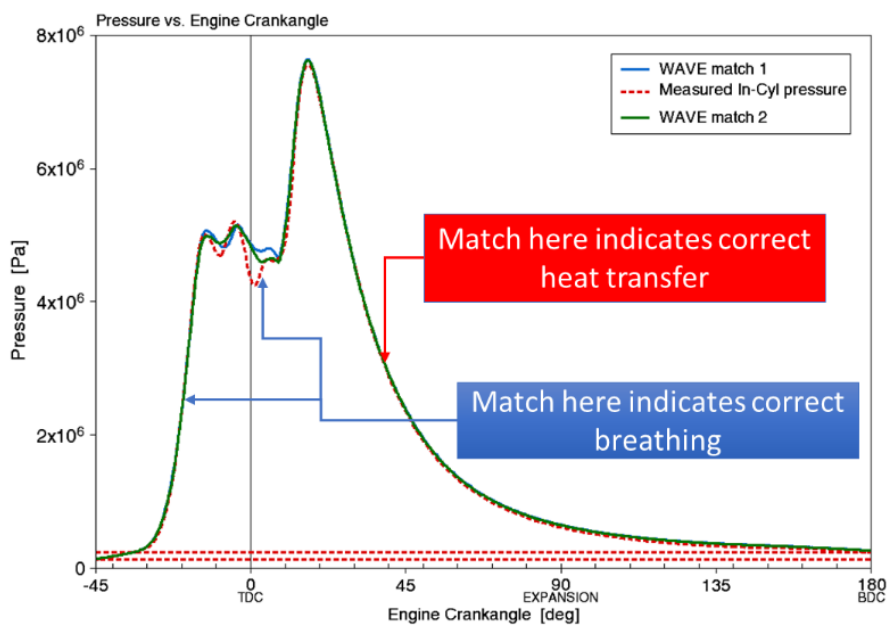

Figure 8: Matching of modelled and measured pressure traces

\section{Recuperator Design}

\section{The Pin-Plate Recuperator}

At this point it is worth considering the parallel optimisation of the recuperator. This component deserves special consideration as it is the only major component that is new compared to the standard 4stroke engine. Recuperation is well known in industrial gas turbines below $1 \mathrm{MWe}$, but working pressures are generally below 4 bar. Gas turbine recuperators are typically manufactured from stamped thin foils as gas-gas heat exchange requires large amounts of surface area. A shell and tube heat exchanger was used for the stationary IsoEngine $[10,15,16]$. However, commercial applications, particularly mobile propulsion, requires a different approach, and the pressure capability of the piston compressor, once combined with turbocharging, can easily approach 70 bar or more. The challenge for this application is that the requirements of compactness and low cost are coupled with very high temperature and pressure demands.

The Hiflux recuperator design was originally developed to increase micro-turbine electrical efficiency by extending operating temperatures beyond the $650^{\circ} \mathrm{C}$ limit of typical primary surface compact exchangers. This provided a platform of experience in the design, manufacture and delivery of recuperators proven in the field to operate dependably at $800^{\circ} \mathrm{C}$ for life times in the 10,000 s of hours. An early prototype of this recuperator is used on the Titan single cylinder expander engine $[1,12,13,17]$. This recuperator design is a counterflow type made up of identical cells which consist of pin-plate geometry (Figure 9) in the millimetre range, linked together into stacks by novel flexible manifolding (Figure 10). Advanced manufacturing technologies such as laser micro-welding and pattern recognition automation are incorporated into special purpose machines to achieve the large number of high quality welds between pins and plates.
The features of this recuperator technology are well-suited to the Recuperated Split Cycle Engine. The pin-plate core combines high strength against pressure loads with compact heat transfer and excellent flow characteristics such as low pressure loss, good flow mixing and distribution. The patented laser-welded core construction allows a wide range of materials, including mixed metals for reduced cost, and can be optimised to meet specific performance needs. The unique flexible manifolding accommodates large thermal displacements. Careful transition of component thicknesses avoids thermal shock issues. This technology also compares well against alternatives in general terms, as large surface area for heat transfer and thermal compliance is achieved without use of very thin foils. Compactness is achieved without the need for costly diffusion bonding/PCHE. Robustness is achieved without occupying the volume of shell and tube. More specifically, the manufacturing process is modular and adaptable, providing wide scope to target unusual performance criteria through size of pin arrays, core stack size and several other geometry factors.

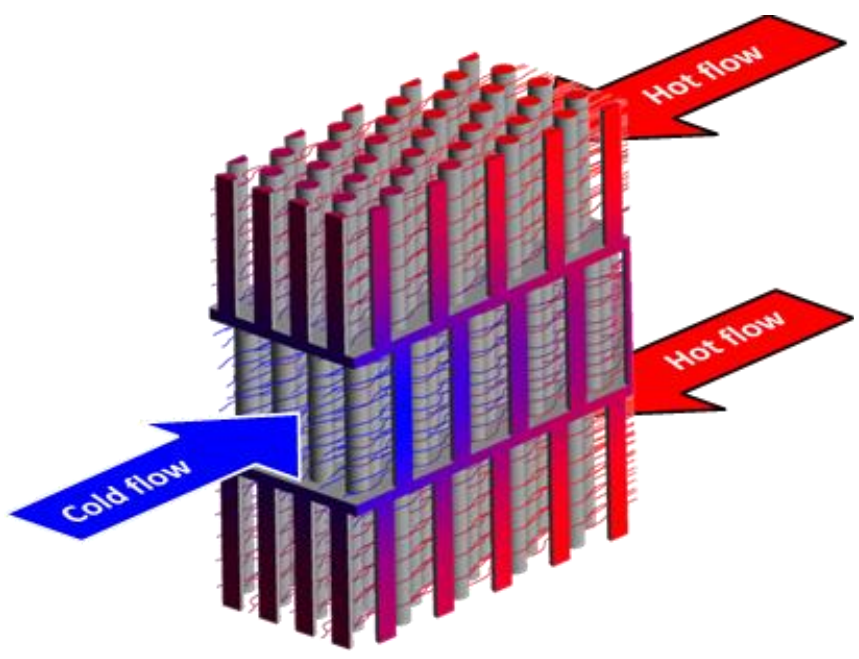

Figure 9: Heat exchange in counterflow pin-plate geometry

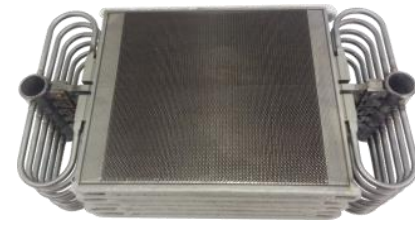

(a)

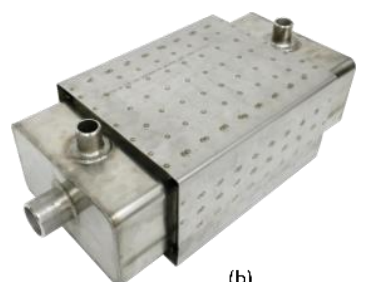

(b)
Figure 10: Example cell stack (a) within recuperator (b)

As a critical component to realising the high system efficiencies, the recuperator optimisation was initially decoupled, then integrated within the wider engine optimisation.

\section{Decoupled Recuperator Optimisation}

Whilst the recuperator development cannot be completely decoupled, key areas can be pursued in parallel with less frequent integration into the engine development: in the context of the split cycle, the recuperator needs to be designed for strength at high temperature. 
Hydraulic tests have demonstrated that laser-welded pin-plate cells withstand more than 1000 bar at room temperatures. Operation in gas turbines has demonstrated long term reliability of cells at turbocharger pressures and $800^{\circ} \mathrm{C}$. However, operation at both high pressure and high temperature brings the material and structure deeper into the creep regime - a challenge familiar in the design of turbine blades. As a time-based phenomenon, creep deformation is the accumulation of strain under long-term stress and in principle requires long term testing to establish the characteristics with fidelity. There are also limits to a basic look-up approach to life-design as found, for instance, in pressure vessel code. This codifies standard heat exchanger types but does not address higher temperatures and indicates that for non-standard (innovative) structures, criteria can be matched through detailed modelling such as Finite Element Analysis.

Operation at both high pressure and temperature presents competing aims: stiffness to contain high pressure loads and flexibility to allow differential thermal expansion. The overall design, of stiff cores flexibly linked, effectively decouples these conflicting requirements and enables clear design goals for high pressure components. Underlining these design goals is the ability to characterize creep not only within the part shapes but also within the alloys chosen in the material state created by the manufacturing processes. The alloy selection, especially for the hot end of the recuperator, must satisfy high resistance to creep, oxidation and corrosion. Inconel 625 is a suitable nickel superalloy for this end, while a stabilized stainless steel may be appropriate for mixing in towards the cooler end.

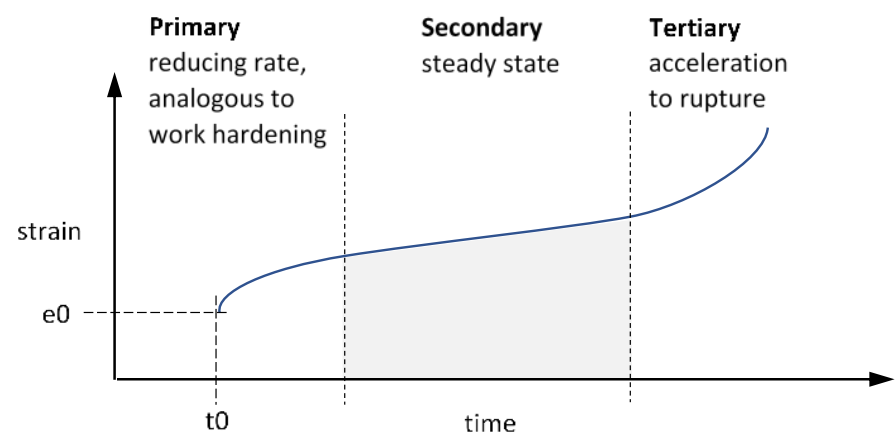

Figure 11: Stages of Creep.

While creep covers a range of microstructural flow mechanisms, it is typically characterised by a steady state process (Figure 11) where primary and tertiary stages are neglected, and failure is indicated by damage criteria. Data from supplier multi-batch testing is often portrayed as clear logarithmic curves, but contains large scatter, irregularities and limited long-term data, compromising the use of simpler methods for accurate life prediction. The limitations of using supplier data alone are compounded by the effect of specific manufacturing processes on material state. However, work in conjunction with academic partners is adding to the knowledge base, augmenting the design for creep through both modelling and testing. Using an approach combining Monkman-Grant and Wilshire techniques $[25,26]$ the stress-rupture data can be collapsed into master curves to characterize the material flexibly and accurately. This approach is being applied within a test program to candidate alloys in material states representing manufacturing processes as the basis for full creep modelling (Figure 12). The test plan will corroborate alloy supplier data and provide detailed imaging of creep strain deformation for simplified versions of pin-plate joint geometries as well as prove creep strength on accelerated tests of sample laser-welded cells. In parallel, FE modelling capability is Page 7 of 12 being built up towards complete damage simulation for critical components, with good early correspondence between model and test
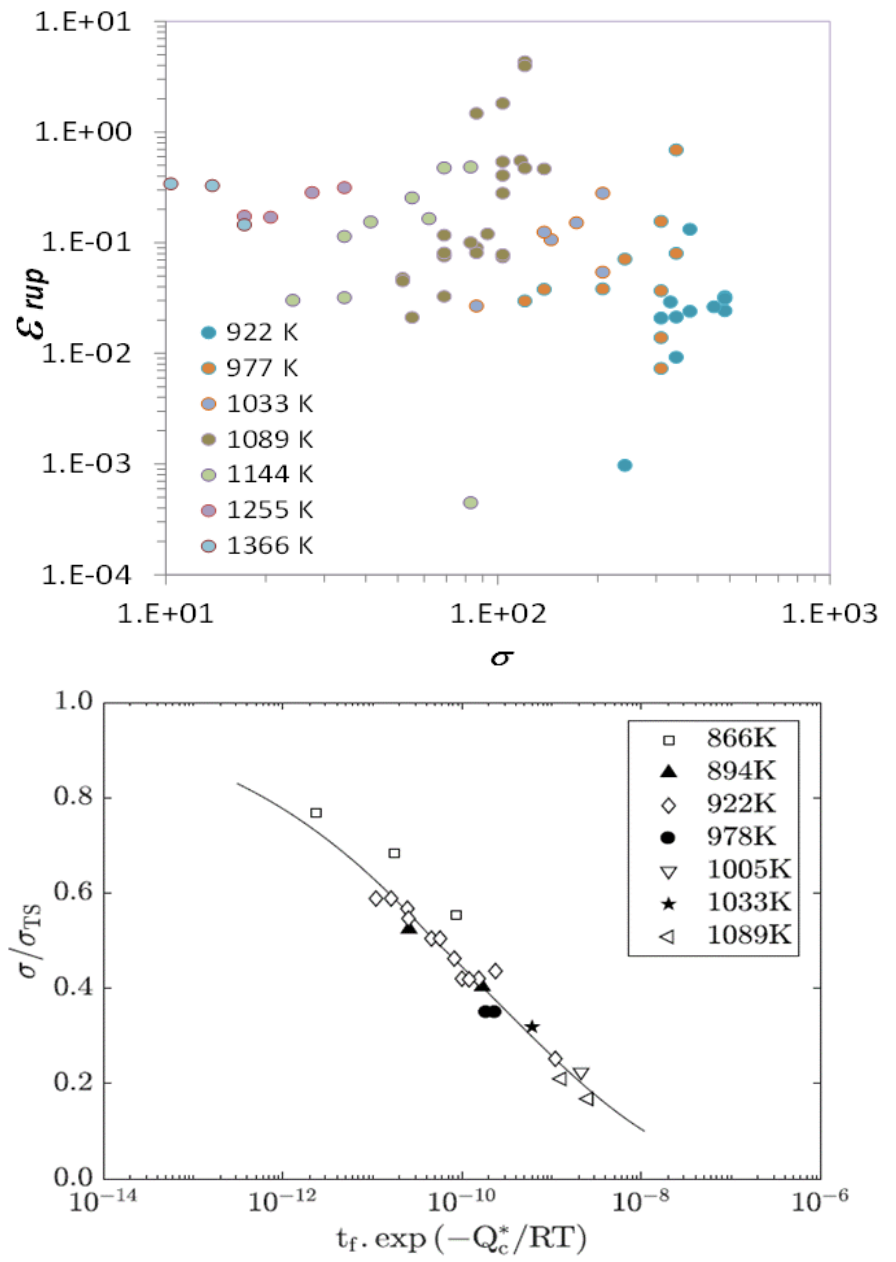

Figure 12: Master creep rupture curve (applied to one of several possible material states)

(Figure 13). These data are used to derive a high-level relationship between maximum acceptable pressure and temperature for a given recuperator life, using either $1 \%$ yield or rupture as a criterion (figure 14). These curves were used to establish the pressure and temperature limits described in the preceding section.

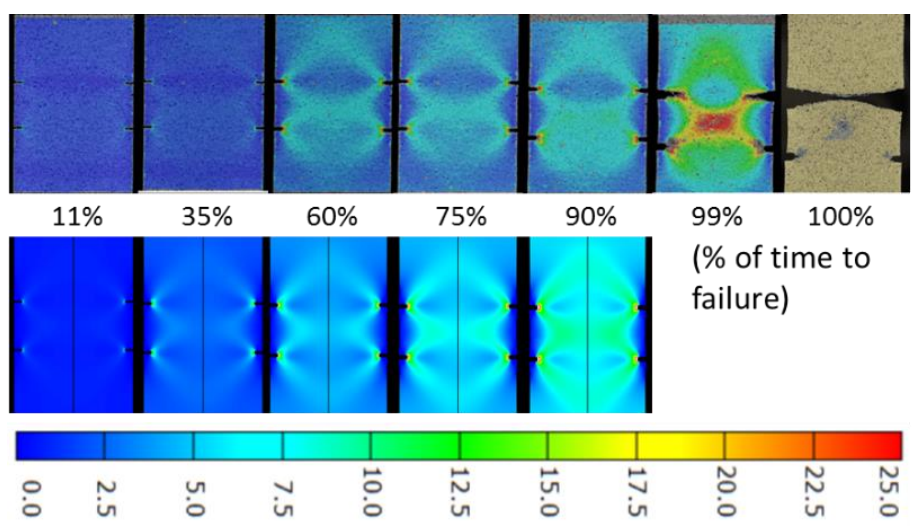

Figure 13: Initial correspondence between test and model of creep strain development at $\%$ of time to failure 


\section{Integrated Recuperator Optimisation}

Integrated optimisation has provided insights both directions. At a general level, feedback on the location of turbine with respect to recuperator, described in the next section, has assisted in the decision for a simpler requirement of the recuperator, allowing work to be concentrated on the key strength considerations of the high pressure components. At more detailed levels, geometry and performance characteristics of the recuperator are being progressively introduced into the WAVE environment to inform the steady state behaviour of the overall engine as well as participate in dynamic response with crank angle.

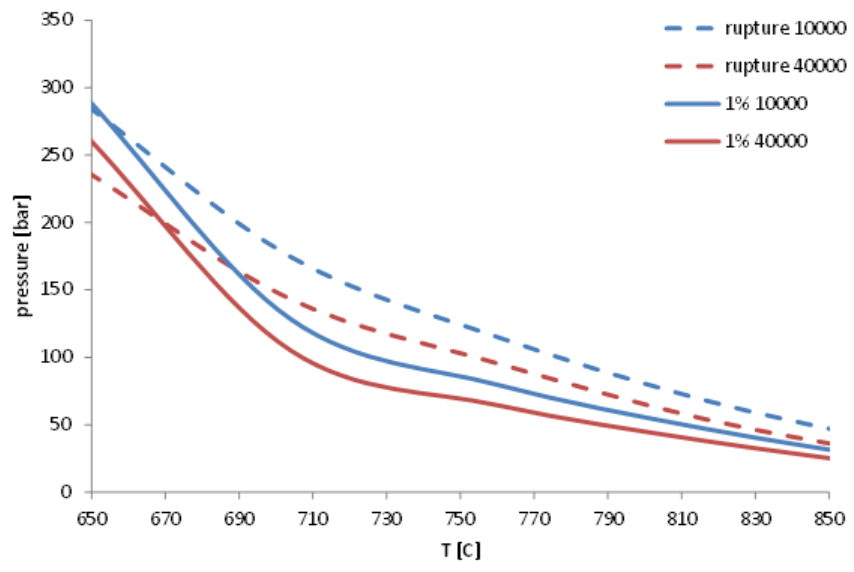

Figure 14: Indicated failure curves (applied to one permutation of core geometry and material state)
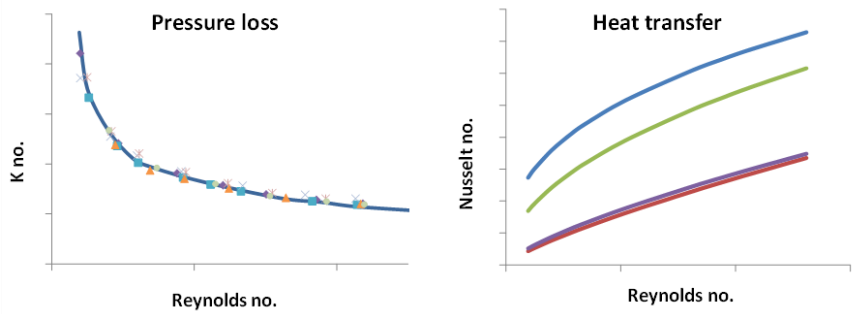

Figure 15: Empirically-based performance correlations (illustrative)

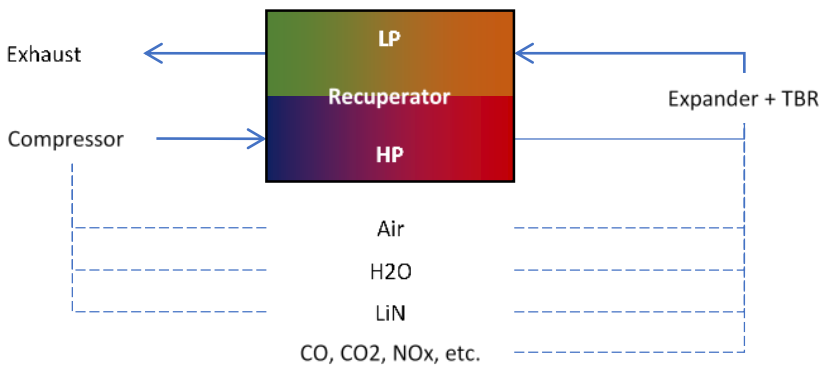

Figure 16: Fluid mixtures within recuperator

A finite element model of the recuperator has been developed, with customised elements to discretise a heat exchanger domain. This effectively models steady state conjugate heat transfer and pressure loss across all features of the recuperator, including the pin array, plates and manifolding. This incorporates experimentally-derived Page 8 of 12 correlations for heat transfer and pressure loss (illustrated in Figure $15)$ which are continually updated with both internal and partner test results. Symmetry assumptions keep the number of elements low for efficient computation. Building on the software's capability to model ideal and real fluids, arbitrary fluid mixtures are being phased in to assess the impact of different fluid mixes within the split cycle configurations (Figure 16).
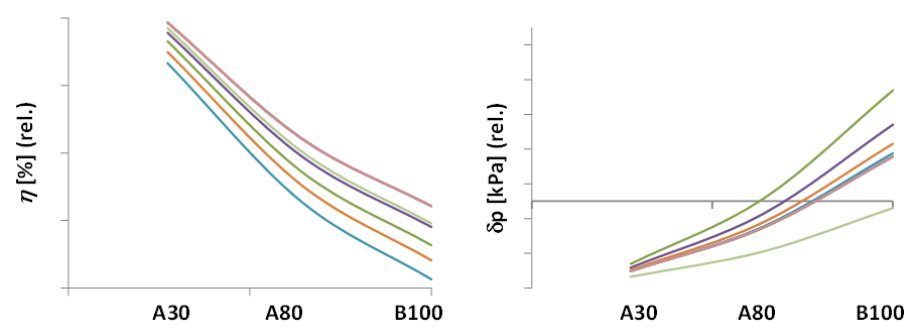

Figure 17: Relative performance response of recuperator configurations at engine key-points (illustrative)

The program can work with both manual and batch input of design parameters and operating conditions, making it versatile in exploring design sensitivities and hunting optima for customer requirements. This versatility has been employed against specifications output from the WAVE engine modelling in a process that can be described as matrix filtering. The specifications provide a matrix of drivers (mass flows, pressure and temperatures at keypoints), primary requirements (effectiveness, pressure loss) and secondary requirements (size, envelope dimensions, volume and mass) that are then matched through screening a matrix of potential recuperator configurations. In terms of the specifications, a valuable area for feedback has been the introduction of realistic performance characteristics at keypoints (Illustrated in Figure 17). In terms of configurations, the large difference in volumetric flow rate between the LP and HP streams can be accommodated by variations in pin geometry either side of the pin-plate structure which can achieve a range of flow area ratios between 2:1 and 5:1; cell number, length and width can be tuned for different balances of pressure loss and effectiveness. This enthalpy play-off can then be fed back to the engine modelling.

\section{Engine Optimisation Approach}

\section{Turbocharger Position}

Before performing a parametric optimisation, one remaining question was the position of the turbocharger - turbine before (TBR) or after the recuperator (TAR). For the basic Dry ThermoPower variant (no compression cooling), this was a straightforward decision, as placing the recuperator upstream gave rise to a predicted metal temperature in the recuperator (taken as the average of the two gas streams) of $900^{\circ} \mathrm{C}$. While such temperatures are seen in engine components (such as turbochargers), those parts are not subjected to 70 bar pressure. The limiting factor here is creep resistance, as described in the previous section.

However, the compression cooling of the CryoPower variant enabled a lower temperature. Therefore, the two configurations were compared over a swing of recuperator effectiveness, a lower effectiveness being less efficient but limiting cycle temperatures. The results are shown in Figure 18 for a $\mathrm{LiN}$ to Fuel ratio of 3:1. The efficiency gap between the two configurations appears to be at least $1.3 \%$ ITE in favour of Turbine After Recuperator (TAR). However, 
when a temperature limit is imposed on the TAR configuration, the advantage over best Turbine Before Recuperator (TBR) drops to below 1\% ITE. The TBR configuration also has the advantage of subjecting the low pressure side of the recuperator to no more than aftertreatment back-pressure, which simplifies its construction, and it is the only feasible configuration for Dry ThermoPower. For these reasons, the Turbine Before Recuperator layout was adopted for further optimisation.

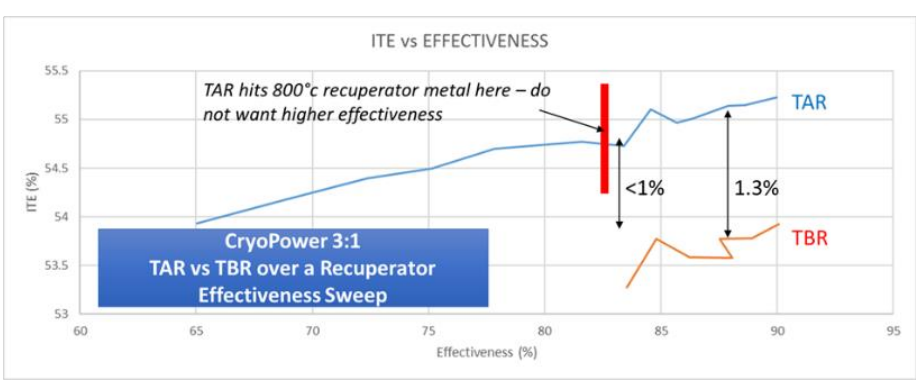

Figure 18: Indicated Thermal Efficiency response to recuperator effectiveness

\section{Design of Experiments Optimisation}

Table 4: DoE variables for optimisation.

\begin{tabular}{|c|c|c|c|}
\hline Parameter & Base Value & Swings & Notes \\
\hline $\begin{array}{l}\text { Compressor } \\
\text { Capacity }\end{array}$ & 1.051 & $\begin{array}{l}-20 \% \text { to } \\
+40 \%\end{array}$ & $\begin{array}{l}\text { Swung by adjusting } \\
\text { stroke. Represents } \\
\text { induction capacity. }\end{array}$ \\
\hline $\begin{array}{l}\text { Expander } \\
\text { Dead } \\
\text { Volume }\end{array}$ & $\begin{array}{l}5 \% \text { of } \\
\text { displace- } \\
\text { ment }\end{array}$ & $\begin{array}{l}-20 \% \text { to } \\
+20 \%\end{array}$ & $\begin{array}{l}\text { Represents ability to } \\
\text { "swallow" compressor } \\
\text { output, and expansion } \\
\text { ratio }\end{array}$ \\
\hline $\begin{array}{l}\text { Expander } \\
\text { Capacity }\end{array}$ & 4.01 & $\begin{array}{l}-20 \% \text { to } \\
+20 \%\end{array}$ & $\begin{array}{l}\text { Swung by adjusting } \\
\text { stroke, represents } \\
\text { expansion ratio }\end{array}$ \\
\hline $\begin{array}{l}\text { Expander } \\
\text { Intake Valve } \\
\text { Timing }\end{array}$ & $\begin{array}{l}\mathrm{IVO}=12^{\circ} \mathrm{B} \\
\text { TDC }\end{array}$ & $\begin{array}{l}15^{\circ} \\
\text { BTDC } \\
\text { to } 5^{\circ} \\
\text { ATDC }\end{array}$ & $\begin{array}{l}\text { Exhaust valve closure } \\
\text { set to IVO }\end{array}$ \\
\hline $\begin{array}{l}\text { Expander } \\
\text { Intake Valve } \\
\text { Period }\end{array}$ & $21^{\circ}$ crank & $\begin{array}{l}18^{\circ} \text { to } \\
26^{\circ}\end{array}$ & $\begin{array}{l}\text { Lift is scaled for } \\
\text { constant acceleration }\end{array}$ \\
\hline $\begin{array}{l}\text { Combustion } \\
\text { Timing }\end{array}$ & $\begin{array}{l}\text { Starts at } \\
\text { IVC }\end{array}$ & $\begin{array}{l}\text { IVC to } \\
+25^{\circ}\end{array}$ & $\begin{array}{l}\text { Retard increases } \\
\text { enthalpy to turbo \& } \\
\text { recuperator }\end{array}$ \\
\hline $\begin{array}{l}\text { Exp Exhaust } \\
\text { Valve } \\
\text { Opening }\end{array}$ & $148^{\circ} \mathrm{ATDC}$ & $\begin{array}{l}120^{\circ} \text { to } \\
160^{\circ}\end{array}$ & $\begin{array}{l}\text { Impacts exhaust } \\
\text { enthalpy for turbine \& } \\
\text { recuperation }\end{array}$ \\
\hline $\begin{array}{l}\text { Recuperator } \\
\text { Effectiveness }\end{array}$ & $88 \%$ & $\begin{array}{l}86 \% \text { to } \\
92 \%\end{array}$ & $\begin{array}{l}\text { Tradeoff of efficiency } \\
\text { vs peak temps \& unit } \\
\text { size }\end{array}$ \\
\hline
\end{tabular}

The next stage was a more structured approach to detailed optimisation. This was performed at three keypoints, as described in Table 3 above. A30 and A80 keypoints were used for efficiency optimisation, with equal weight. The B100 keypoint was used as a check on power, which was matched to a benchmark engine at $125 \mathrm{~kW}$ (brake) per pair. Eight variables were selected for the main optimisation matrix, as described in Table 4. An optimal Latin Hypercube was constructed around these variables, with 150 test points per speed/load keypoint. The Dry ThermoPower and CryoPower concepts were optimised independently; a LiN to Fuel ratio of 3:1 was chosen for the CryoPower concept, as it represents an upper limit of both packaging and economic feasibility.

Results were processed using an auto-optimisation routine, to obtain a best solution that met target power, and respected the limits for recuperator and turbocharger temperatures previously discussed. The tool was then used to examine the impact of further practical compromises, such as fixing valve timing across all operating points.

\section{Results and Discussion}

\section{Parametric optimisation}

Figure 19 shows the response of Indicated Thermal Efficiency to swings in the eight optimisation parameters, for both the Dry ThermoPower and CryoPower variants. The strongest responses are to the timing of the expander intake and combustion events (columns $4 \& 6$ ), where early valve closure followed by a rapid start of combustion give the greatest efficiency. This is an expected response, suggesting that recuperation does not fully compensate the inefficiencies arising from retarded combustion. There is less sensitivity to the duration of the expander intake event, which is useful in permitting a slightly less aggressive period.

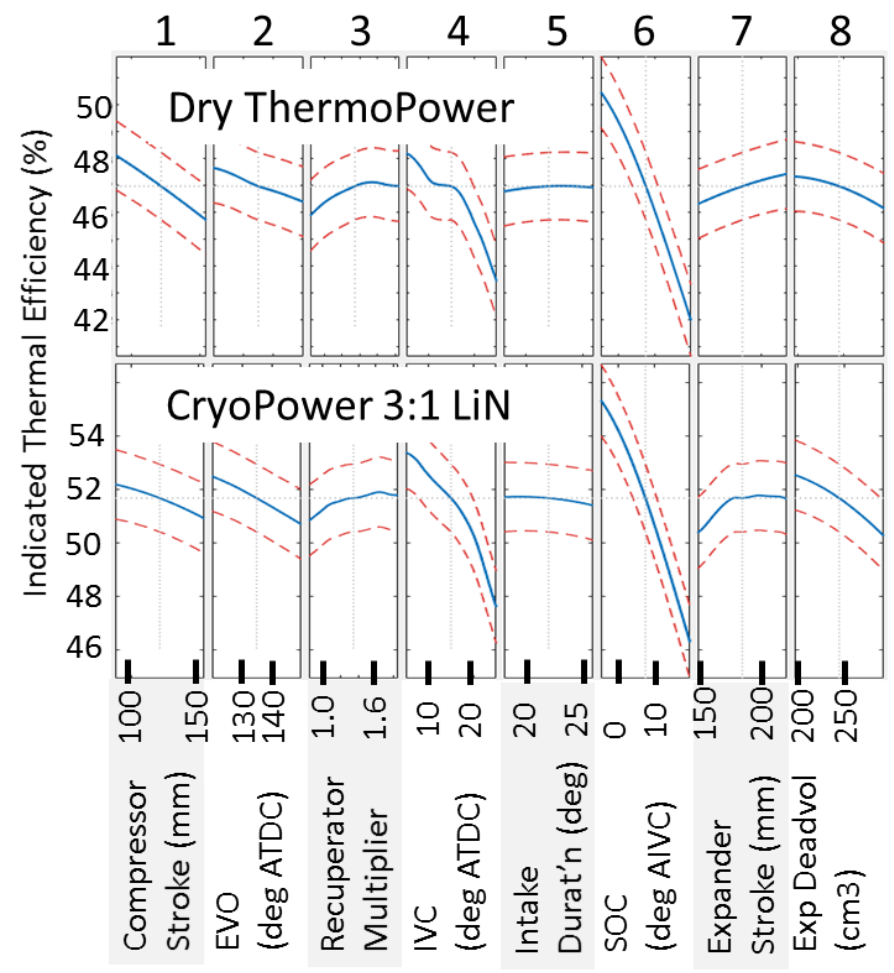

Figure 19: Response of ITE to parameter swings

The next set of trends relate to the relative sizes of compressor and expander, with the results suggesting that a small compressor feeding a small expander dead volume (columns 1 and 8 ), are beneficial, as is

Page 9 of 12 
a larger expander. It is believed that two physical factors create this trend. Firstly, the optimisation did not constrain boost pressure, and turbomachine efficiencies were fixed - this tends to drive a solution where the intercooling occurs farther along the overall compression process. And secondly, since extra efficiency can only be obtained through extra expansion of hot gases, this drives a lower rating and larger expander. As a result, the optimum compressor to expander size ratio was predicted as 3.7 for the Dry ThermoPower concept, and 4.5 for CryoPower, where injection of $\mathrm{LiN}$ was observed to cool the incoming charge in the compressor, giving better volumetric efficiency. Later work with real single-stage turbocharger maps shifted the optimum compressor to expander ratio to around 3:1 for both types, to take advantage of the most efficient turbomachine pressure ratios. Optimised ratings in this study were $22 \mathrm{~kW} / 1$ for Dry ThermoPower and $25 \mathrm{~kW} / 1$ for CryoPower.

\section{Valve Timing Strategy}

The optimisation of geometry from the results matrix was compared under two scenarios. In the first, the timing of intake valve events was allowed to float, while in the second, it was fixed. As shown above, efficiency is relatively insensitive to intake valve duration, so the main variable would be phasing. Figure 20 compares the resulting Indicated Thermal Efficiencies for the CryoPower variant, and shows up to $1 \%$ ITE benefit to variable timing. This would be relatively easy to achieve, as the concept requires intake phasing to achieve a cold start. However, the optimum fixed-timing geometries were found to have greater commonality of other parameters between Dry ThermoPower and CryoPower, so it was decided to adopt the fixed timings and return to phase optimisation with a multi-cylinder model.

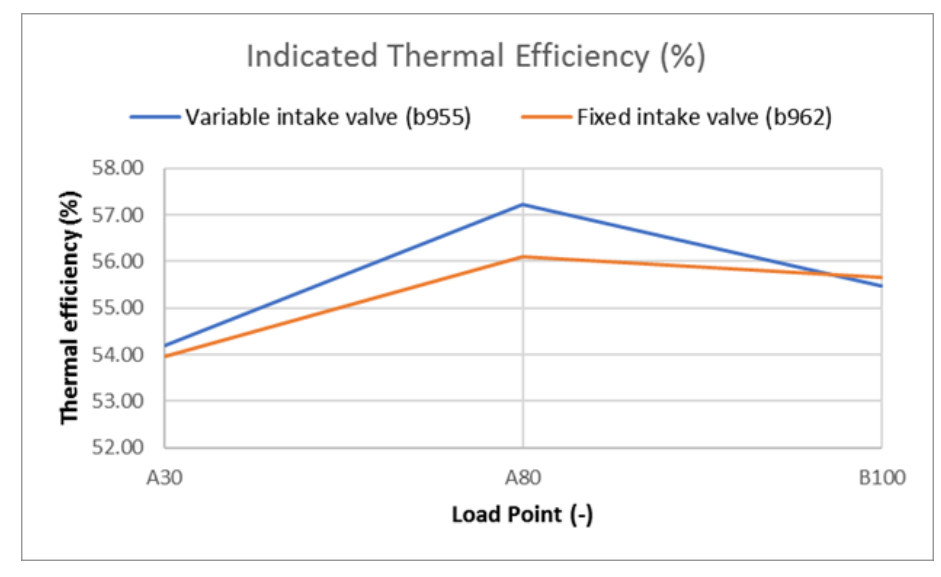

Figure 20: Predicted efficiencies for Fixed and Variable Valve Timing

\section{Specific Fuel Consumption Comparisons}

Having established optimum, fixed valve timing geometries for Dry ThermoPower and CryoPower, a single model run was added for the intermediate Wet ThermoPower variant. Here, the proximity of water's boiling point to compressor-cylinder conditions necessitated a more detailed model of the evaporation process, including modelling of the water film in the compressor. As this was computationally intensive, just the A80 keypoint was modelled, but this exercise confirmed the potential for this variant to offer an intermediate level of efficiency improvement. The maximum amount of water injected before some remained as liquid was circa $1 / 3$ of the fuel consumed.
Predicted efficiencies of the three concepts were post-processed by adding the friction model, then corrected for a lower installed cooling fan power (both described in a preceding section). Figure 21 shows the results, converted to a "corrected BSFC" and compared to a data range for typical medium and heavy duty engines. The results show that the three technology variants each offer significant, and roughly equal, steps of improvement in fuel consumption, with each step representing around $8 \%$ less fuel used compared to the best baseline, or previous step.

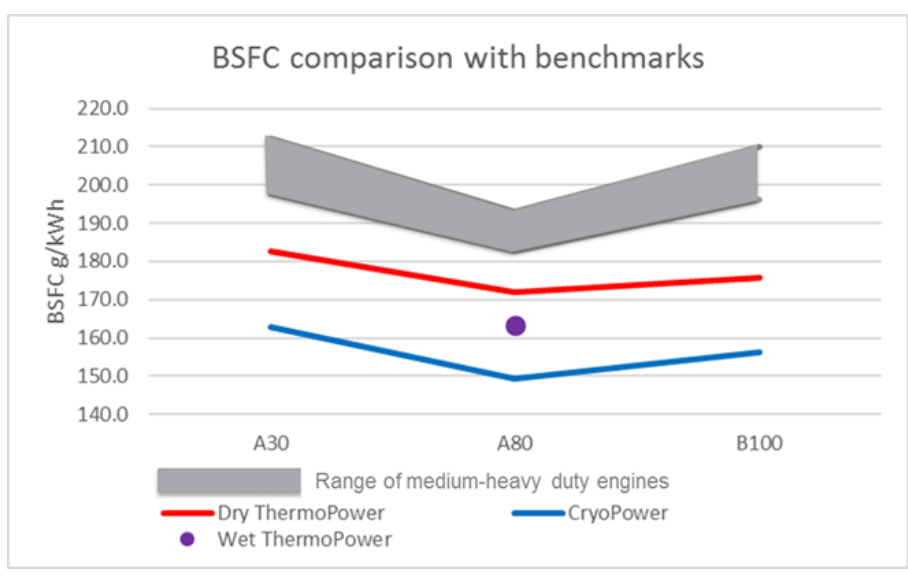

Figure 21: BSFC comparisons with benchmarks

\section{Economic Comparisons}

For any fuel saving technology, it is necessary to consider the balance between operational expenditure saved (essentially the cost of fuel, unless utilisation or servicing are impacted) and extra capital expenditure. For the ThermoPower variants this is all that is required, although water for injection to the compressor would incur a small cost. For CryoPower, it is necessary also to consider the cost of the liquid nitrogen.

Table 5: Assumptions for economic comparison

\begin{tabular}{|c|c|c|}
\hline Value & Assumption & Notes \\
\hline $\begin{array}{l}\text { Base vehicle fuel } \\
\text { consumption }\end{array}$ & $\begin{array}{l}7.02 \text { miles per } \\
\text { UK } \text { gallon } \\
(40.241 / 100 \mathrm{~km})\end{array}$ & $\begin{array}{l}\text { Represents a typical UK } \\
\text { heavy goods vehicle }\end{array}$ \\
\hline $\begin{array}{l}\text { Base vehicle } \\
\text { annual mileage }\end{array}$ & $\begin{array}{l}75,000 \text { miles } \\
(120,000 \mathrm{~km})\end{array}$ & $\begin{array}{l}\text { Represents a typical UK } \\
\text { heavy goods vehicle, } \\
\text { though long-haul trucks } \\
\text { may go } 30-50 \% \text { farther }\end{array}$ \\
\hline Diesel Price & $£ 1.25 /$ litre & $\begin{array}{l}\text { Represents fully taxed } \\
\text { price }\end{array}$ \\
\hline LiN Price & $£ 0.037 /$ litre & Refer to [26], Chapter 5 \\
\hline $\begin{array}{l}\text { Dry } \\
\text { ThermoPower add } \\
\text { cost }\end{array}$ & $€ 5,175$ & $\begin{array}{l}\text { Recuperator, VVA, } \\
\text { Insulation } \\
\text { (remainder assumed } \\
\text { similar to } 4 \text { stroke diesel) }\end{array}$ \\
\hline $\begin{array}{l}\text { Wet } \\
\text { ThermoPower add } \\
\text { cost }\end{array}$ & $€ 6,325$ & $\begin{array}{lll}\text { Add Water } & \text { Tank } & \& \\
\text { Injectors, frost } & \& \\
\text { limescale measures } & \end{array}$ \\
\hline $\begin{array}{l}\text { CryoPower } \\
\text { Add cost }\end{array}$ & $€ 9,315$ & $\begin{array}{l}\text { Add instead Cryo Tank } \\
\& \text { Injectors, Safety } \\
\text { equipment }\end{array}$ \\
\hline
\end{tabular}


Table 5 lists the assumptions used for the economic comparison. The assumed vehicle is a typical UK truck, with typical UK mileage; the Diesel price is typical at the time of writing. The price of $\mathrm{LiN}$ varies strongly with volume supplied, and is below typical "merchant" prices today, however (as with Hydrogen) increasing demand from widespread uptake in transport will drive a lower price; the assumption is similar to other published estimates [27]. Comparisons were made by weighting the fuel saving over the three keypoints in the ratio 40\% (A30), 40\% (A80) and 20\% (B100). For the baseline, the best (most efficient) premium truck engine at the lower edge of the BSFC range in Figure 21 was used, as these premium long-haul trucks represent a more likely market entry point. Table 6 presents the outcome of this analysis.

Table 6: Comparison of efficiencies, fuel savings and payback

\begin{tabular}{|c|c|c|c|c|c|}
\hline & 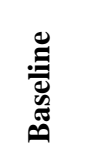 & 总离离 & 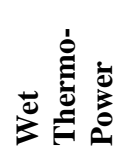 & 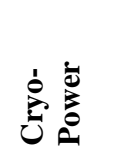 & 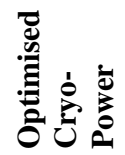 \\
\hline $\begin{array}{l}\text { BTE (Fan } \\
\text { Corrected) } \\
\text { A30 } \\
\text { A80 } \\
\text { B100 }\end{array}$ & $\begin{array}{l}42.4 \% \\
45.9 \% \\
42.8 \% \\
\end{array}$ & $\begin{array}{l}45.9 \% \\
48.7 \% \\
47.7 \% \\
\end{array}$ & $51.3 \%$ & $\begin{array}{l}51.5 \% \\
56.1 \% \\
53.6 \% \\
\end{array}$ & $60 \%$ \\
\hline $\begin{array}{l}\text { Weighted } \\
\text { BSFC } \\
\text { saving }\end{array}$ & Base & $7.5 \%$ & $14.6 \%$ & $18.3 \%$ & $23.7 \%$ \\
\hline $\begin{array}{l}\text { Annual Cost } \\
\text { Saving }(€)\end{array}$ & Base & $€ 5,175$ & $€ 10,235$ & $€ 7,705$ & $€ 11,500$ \\
\hline $\begin{array}{l}\text { Payback } \\
\text { Time on } \\
\text { Add Cost }\end{array}$ & Base & 1 year & $\begin{array}{l}8 \\
\text { months }\end{array}$ & $\begin{array}{l}15 \\
\text { months }\end{array}$ & $\begin{array}{l}10 \\
\text { months }\end{array}$ \\
\hline $\begin{array}{l}3 \text { year TCO } \\
\text { saving }(€)\end{array}$ & Base & $€ 10,350$ & $€ 24,380$ & $€ 13,800$ & $€ 25,185$ \\
\hline
\end{tabular}

Every variant offers paybacks that are attractive in the context of the heavy duty sector. At this stage of optimisation, the simpler ThermoPower concepts seem more attractive, and would avoid the need to deploy a widespread $\mathrm{LiN}$ infrastructure or find space to package LiN tanks on the vehicle. However, the work performed to date indicates that the CryoPower concept has scope for further optimisation, especially of the timing of LiN injection. And reference to Figure 2 shows also that there is scope for a system that injects LiN early in the compression process, and a small quantity of water later. Such a system would be far easier to justify and deploy in the stationary power generation sector, where low cost on-site liquefaction can be used to absorb stranded wrong-time renewables air liquefaction is already being rolled out for this purpose $[27,28]$. A final column in Table 6 shows that an improved CryoPower, embracing optimised compression and reverting to the turbine-afterrecuperator layout, becomes more competitive even at vehicle scale.

\section{Conclusions}

A suite of recuperated split-cycle engine concepts, Dry ThermoPower, Wet ThermoPower and CryoPower, has been proposed and modelled, as sustainable solutions for the heavy duty sectors including medium to heavy duty trucks, rail, shipping, agriculture, construction, and distributed power generation. Specifically:

Page 11 of 12
- An industry-standard simulation tool has been adapted successfully to represent the thermodynamics of the recuperated split cycle

- Subsystem validation has been implemented to ensure that critical systems such as valvetrain, compression coolants, thermal insulation and recuperation are correctly modelled

- A Design-of-Experiments optimisation has shown that a similar, and practically achievable, engine configuration and geometry can be used for all three variants

- Brake thermal efficiencies of $49 \%$ to $56 \%$ were predicted, with a route to $60 \%$ identified from observations made during the study. The fuel consumption savings arising give a user payback of a year or less, based on added capital costs, and CO2/GHG savings of $8-24 \%$ depending on the technology variant

- A parallel publication on the engine's low emissions potential shows that SULEV tailpipe NOx (or 5\% of EuVI/US10 levels) is readily achievable; with development and high efficiency after-treatment, near-zero (1/10 of SULEV) is possible

This study has not looked at the de-carbonisation of either the combustion fuel or, for the CryoPower variant, Liquid Nitrogen. Industrial air separation is already a major player in electricity demand management, and liquified air is being used to store wrongtime renewable power. A clean, highly efficient engine with control over both air and fuel at the point of combustion is a useful partner for biofuels, synthetic e-fuels, green ammonia fuel, and captured fugitive biomethane in a future energy economy.

\section{References}

1. Morgan, R., et al., "The Ultra Low Emissions Potential of the Recuperated Split Cycle Combustion System”, SAE paper 201924-0189, 2019.

2. European Road Transport Advisory Council, "European Roadmap - Electrification of Road Transport", 3rd edition, Version 10, June 2017.

3. UK Department for Transport, "The Road to Zero - Next steps towards cleaner road transport and delivering our Industrial Strategy", DfT, July 2018.

4. Tolley, A., "The Particular Challenges for Off-Highway and Heavy Duty Machines as we move to a Low Carbon, Zero Emissions future", Future Powertrain Conference, UK, 2019

5. American Machinist Magazine, "The Backus Gas Engine", January 15th, 1891.

6. Ricardo, H. R., and Hempson, J.G.G., "The High-Speed Internal-Combustion Engine”, ISBN-13: 978-0216890268, 1968.

7. Phillips F., Gilbert I., Pirault J-P. and Megel M., "Scuderi Split Cycle Research Engine: Overview, Architecture and Operation", SAE paper 2011-01-0403, 2011.

8. Branyon, D. and Simpson, D., "Miller Cycle Application to the Scuderi Split Cycle Engine (by Downsizing the Compressor Cylinder)", SAE paper 2012-01-0419, 2012.

9. Sud, K., Cetinkunt, S., and Fiveland, S. B., "A Simulation Based Comprehensive Performance Evaluation of Cat ${ }^{\circledR}$ C4.4 Current Production Engine with its Split Cycle Clean Combustion Variant using a Validated One-Dimensional Modeling Methodology", SAE paper 2013-01-2434, 2013.

10. Coney, M., Linnemann, C., Morgan, R., et al., "A Novel Internal Combustion Engine with Simultaneous Injection of Fuel and Pre-Compressed, Pre Heated Air," Proceedings ASME 2002 Fall Technical Conference, September 2002, New Orleans, USA, ICE-Vol. 39, pp. 67-77. 
11. Finneran, J., Garner, C., Bassett, M., and Hall, J., "A Review of Split-Cycle Engines", International Journal of Engine Research, 2018, doi:10.1177/1468087418789528.

12. Morgan, R., Khalid, F., Atkins, A. et al, "Towards zero emission engines through the adoption of combustion lead engine design realised using a split cycle topology", THIESEL 2018

Conference on Thermo- and Fluid Dynamic Processes in Direct Injection Engines.

13. Morgan, R., "Technologies for Clean Engines", Future Powertrain Conference, UK, 2019

14. Jackson, N., and Wotton, C., "The effects of ceramic thermal insulation on DI diesel engine combustion, emissions and heat transfer", Conference on Ceramic Applications in Reciprocating Engines, Coventry, 1990.

15. Coney, M., Linnemann, C., and Abdallah, H., "A thermodynamic analysis of a novel high efficiency reciprocating internal combustion engine- the isoengine", Energy 29 (2004) 2585-2600.

16. Coney, M., Linnemann, C., Sugiura, K., and Goto, T., "Isoengine Data Analysis and Future Design Options", CIMAC Congress 2004, Kyoto, Paper No. 83.

17. Jackson, N., Atkins, A., Eatwell, J., and Morgan, R., "An Alternative Thermodynamic Cycle for Reciprocating Piston Engines", 36th International Vienna Motor Symposium, 7-8 May 2015, doi:10.1007/s35778-015-0029-6.

18. Owen, N., "CryoPower - A long-haul truck engine with near zero emissions and high efficiency", Future Powertrain Conference, UK, 2019.

19. Cornwell, R., Thomas, H., Dalby, J., et al, "The Drive for Minimum Fuel Consumption of Passenger Car Diesels: An Analytical Study to Evaluate Key Architectural Choices", SAE paper 2015-24-2519, 2015, doi: 10.4271/2015-24-2519

20. Owen, N., Clarke, H., Charters, D. et al, "Development of a high efficiency liquid air engine for cooling, heat recovery and power", IMechE VTMS12 conference, C1400/055/2015, 2015.

21. Owen, N., "Power and Cold - Development of the Dearman Engine", IMechE VTMS13 conference, 2017.

22. Woschni, G., "A universally applicable equation for the instantaneous heat transfer coefficient in the internal combustion engine", SAE paper 670931, 1967.

23. Jackson, N., Pilley, A., and Owen, N., "Instantaneous heat transfer in a highly rated DI truck engine", SAE paper 900692, 1990.

24. Staunton, N., Maughan, R., and Jackson, K., "Reduction of parasitic losses in heavy-duty diesel engine cooling systems", Engine Expo, Stuttgart, 2008.

25. Monkman, F.C., and Grant, N. J., MIT Press, Boston, 1963, vol. 56.

26. Evans, R.W., and Wilshire, B., "Creep of Metals and Alloys", The Institute of Materials, London, 1985.

27. Strahan, D., Morris, R., Peters, T., et al, "Liquid Air on the Highway”, Centre for Low Carbon Futures, 2014, ISBN: 978-09927328-20

28. "Highview Power Storage - 2015 Global Large-Scale Energy Storage Technology Innovation Award”, Frost \& Sullivan, 2015

\section{Contact Information}

Nick Owen

Technical Director, Dolphin N2 Ltd

Nick.owen@dolphin-n2.com

\section{Acknowledgments}

The authors would like to thank the partners of the $\mathrm{StepCO}_{2}$ project for permission to publish this paper: Dolphin N2 Ltd, Ricardo plc, Hiflux Ltd, The University of Brighton, and the Advanced Manufacturing Research Centre with Boeing; also the research team at Imperial College who have supported recuperator material testing. StepCO ${ }_{2}$ is funded by the partnership and the UK's innovation agency, InnovateUK.

\section{Definitions/Abbreviations}

$\begin{array}{ll}\text { AFR } & \text { Air-fuel ratio } \\ \text { ATDC } & \text { After top dead center } \\ \text { BSFC } & \text { Brake specific fuel consumption } \\ \text { BTDC } & \text { Before top dead centre } \\ \text { BTE } & \text { Brake thermal efficiency }\end{array}$

CryoPower Recuperated split cycle engine with LiN compression coolant

DoE Design of Experiments

Dry

ThermoPower

Recuperated split cycle engine without

EVO compression coolant

ICE

ITE

IsoEngine or IsoPower

IVO

rpm

SOI

SULEV

TAR

TBR

TCO

Exhaust valve opening

Internal combustion engine

Indicated thermal efficiency

Recuperated split cycle engine with nonevaporating water compression coolant

Inlet valve opening

Revolutions per minute

Start of injection

Super ultra low emissions vehicle

Turbine after recuperator

Turbine before recuperator

TDC

VVA

VVT

WAVE

Wet

ThermoPower
Total cost of ownership

Top dead center

Variable valve actuation (timing \& phase)

Variable valve timing (phase)

1-d engine simulation tool

Recuperated split cycle engine with water as a partial compression coolant

Page 12 of 12

$10 / 19 / 2016$ 